\title{
$K R A S$ mutation testing for predicting response to anti-EGFR therapy for colorectal carcinoma: proposal for an European quality assurance program
}

\author{
J. H. J. M. van Krieken • A. Jung • T. Kirchner • \\ F. Carneiro • R. Seruca • F. T. Bosman • P. Quirke • \\ J. F. Fléjou • T. Plato Hansen • G. de Hertogh • P. Jares • \\ C. Langner • G. Hoefler • M. Ligtenberg • D. Tiniakos • \\ S. Tejpar • G. Bevilacqua • A. Ensari
}

Received: 24 June 2008 / Accepted: 21 August 2008 / Published online: 18 September 2008

(C) The Author(s) 2008. This article is published with open access at Springerlink.com

\begin{abstract}
Novel therapeutic agents targeting the epidermal growth factor receptor (EGFR) have improved outcomes for patients with colorectal carcinoma. However, these therapies are effective only in a subset of patients. Activating mutations in the KRAS gene are found in $30-40 \%$ of colorectal tumors and are associated with poor response to anti-EGFR therapies. Thus, KRAS mutation status can predict which patient may or may not benefit from anti-EGFR therapy. Although many diagnostic tools have been developed for KRAS mutation analysis, validated methods and standardized testing procedures are lacking. This poses a challenge for the optimal use of
\end{abstract}

J. H. J. M. van Krieken $(\bowtie) \cdot$ M. Ligtenberg

Department of Pathology,

Radboud University Nijmegen Medical Centre,

PO Box 9101, Nijmegen 6500 HB, The Netherlands

e-mail: J.vanKrieken@pathol.umcn.nl

A. Jung $\cdot$ T. Kirchner

Department of Pathology, Ludwig-Maximilians Universität,

Munich, Germany

F. Carneiro $\cdot$ R. Seruca

Institute of Molecular Pathology and Immunology of the

University of Porto (IPATIMUP),

Porto, Portugal

F. Carneiro $\cdot$ R. Seruca

Medical Faculty of the of Porto,

Porto, Portugal

F. Carneiro

Department of Pathology, Hospital S. João,

Porto, Portugal

F. T. Bosman

University Institute of Pathology,

Lausanne, Switzerland
anti-EGFR therapies in the management of colorectal carcinoma. Here we review the molecular basis of EGFR-targeted therapies and the resistance to treatment conferred by KRAS mutations. We also present guideline recommendations and a proposal for a European quality assurance program to help ensure accuracy and proficiency in KRAS mutation testing across the European Union.

Keywords Colorectal carcinoma - Anti-EGFR therapy . KRAS mutation testing · Practice guidelines .

Quality assurance

P. Quirke

Pathology and Tumour Biology,

University of Leeds,

Leeds, England

\section{J. F. Fléjou}

Department of Pathology, Saint-Antoine Hospital,

University Paris 6,

Paris, France

T. Plato Hansen

Department of Pathology, Odense University Hospital,

Odense, Denmark

G. de Hertogh

Department of Pathology, University Hospitals KU Leuven,

Leuven, Belgium

P. Jares

Department of Pathology,

Hospital Clinic,

Barcelona, Spain

C. Langner $\cdot$ G. Hoefler

Institute of Pathology, Medical University Graz,

Graz, Austria 


\section{Introduction}

Novel classes of therapeutic agents for treating cancer are rapidly changing clinical practice. Several of these new drugs target specific molecules expressed by cancer cells. One group targets members of the human epidermal growth factor receptor (HER) family, namely, the epidermal growth factor receptor (EGFR) and the human epidermal growth factor receptor 2 (HER2). Both EGFR and HER2 contribute to the development and progression of several cancers and therefore have been explored as targets for cancer therapy. To apply targeted therapies optimally, it is important to recognize that their activity differs across patient populations and to understand the molecular mechanisms underlying these differences.

A well-defined example of how the efficacy of a targeted therapy can vary among patients with different molecular profiles is the use of trastuzumab (Herceptin ${ }^{\circledR}$ ), an antiHER2 monoclonal antibody, in the treatment of breast cancer. HER 2 is overexpressed in $20-30 \%$ of malignant breast tumors as a result of amplification of the coding gene $[1,2]$. HER2-positive status is associated with poor prognosis and is a strong predictor of response to trastuzumab therapy $[1,3]$. Assessment of HER2 status has become standard practice to identify breast cancer patients most likely to benefit from trastuzumab therapy [3]. In parallel, substantial progress has been made to validate HER2 testing methods and implement quality assurance to ensure consistency and accuracy in HER2 testing [4].

Targeted therapeutic agents have also been developed for the treatment of colorectal cancer, a leading cause of cancer-related deaths worldwide [5]. The majority of patients with colorectal cancer are diagnosed with locally

\section{Ligtenberg}

Department of Human Genetics,

Radboud University Nijmegen Medical Centre,

Nijmegen, The Netherlands

D. Tiniakos

Laboratory of Histology and Embryology,

Medical School University of Athens,

Athens, Greece

S. Tejpar

Digestive Oncology Unit, University Hospital Gasthuisberg,

Leuven, Belgium

G. Bevilacqua

Department of Oncology,

University of Pisa and Pisa University Hospital,

Pisa, Italy

\section{A. Ensari}

Department of Pathology,

Ankara University Medical School,

Ankara, Turkey advanced or metastatic disease which responds poorly to conventional forms of treatment. The drugs recently introduced for treating colorectal cancer target the EGFR, which is overexpressed in $50-80 \%$ of colorectal tumors [610]. Although the advent of EGFR-targeted therapies has improved outcomes for colorectal cancer patients, they are effective in only a subset of patients [11]. Therefore, a major challenge in optimizing EGFR-targeted treatment options in colorectal cancer is to identify reliable biomarkers that can predict which patients will or will not respond to these targeted therapies.

It has become clear that mutations in the Kirsten RAS (KRAS) gene negatively predict success of anti-EGFR therapies. Gain-of-function KRAS mutations lead to EGFRindependent activation of intracellular signaling pathways, resulting in tumor cell proliferation, protection against apoptosis, increased invasion and metastasis, and activation of tumorinduced angiogenesis [12]. Unlike HER2 testing in breast cancer, however, there is a wide variety of testing methods and a lack of quality assurance schemes for the assessment of $K R A S$ mutation status in colorectal cancer patients.

The objectives of this paper are threefold: (1) to review the molecular basis of EGFR-targeted therapies and the resistance to treatment conferred by KRAS mutations; (2) to summarize the different methods available for the detection of KRAS mutations; and (3) to propose guideline recommendations and a European quality assurance (QA) program for KRAS mutation testing in colorectal carcinoma.

\section{Molecular basis of EGFR-targeted therapies}

\section{EGFR and cancer}

EGFR is a $170-\mathrm{kDa}$ transmembrane tyrosine kinase receptor that is present in most epithelial tissues and plays an important role in cell growth and function. Modulation of growth factor receptors, such as the EGFR, is a key strategy used by tumor cells to become self-sufficient and rely less on growth signals for their transformation, proliferation and survival. EGFR is overexpressed in many solid cancers and has been shown by many studies to be involved in the development and progression of human malignancies [12, 13]. Extensive research over the last few years has improved our understanding of the oncogenic role of the EGFR and the mechanisms of receptor activation and function. These advances have led to the development of new treatment modalities aimed at targeting the EGFR signaling system.

EGFR belongs to HER family of cell surface receptors (see Fig. 1a). The HER receptor family consists of four structurally related proteins: EGFR (also called HER1/ ErbB1), HER2 (ErbB2), HER3 (ErbB3), and HER4 (ErbB4). Each receptor is composed of three domains: (1) 

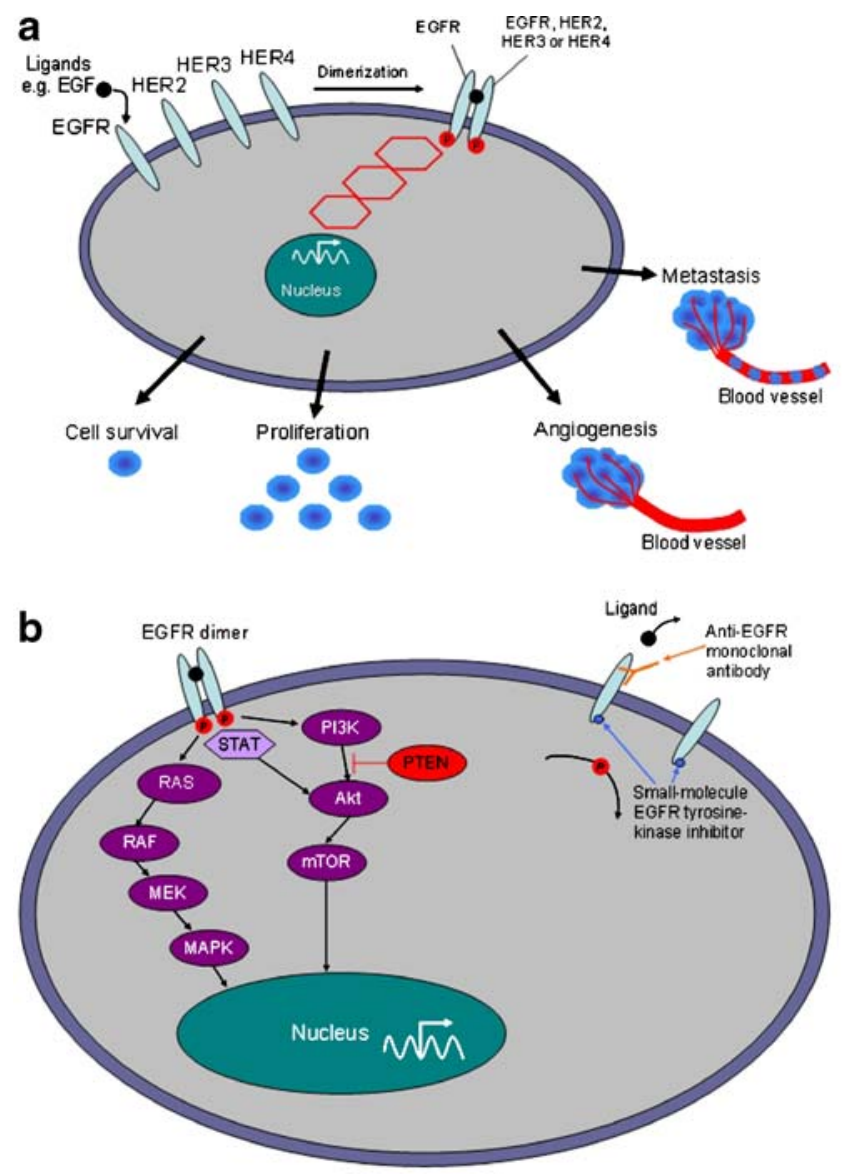

Fig. 1 a Cellular responses controlled by EGFR-dependent intracellular signaling. The binding of specific ligands to the extracellular portion of the EGFR results in the formation of a functionally active EGFR dimer with another ligand-bound EGFR or one of the EGFRrelated receptors (HER2, HER3, or HER4). Receptor dimerization causes ATP-dependent phosphorylation of tyrosine kinase residues within the intracellular domain of the receptors. This tyrosine phosphorylation triggers activation of downstream signal transduction cascades which control cell growth, development, and function. Perturbations in EGFR-dependent intracellular signaling have been implicated in multiple aspects of the malignant process, including enhanced tumor cell survival and proliferation, tumor-induced angiogenesis, and metastasis. b Signal transduction pathways controlled by EGFR activation and two therapeutic approaches to block the EGFR. Ligand-induced stimulation of EGFR induces activation of three major signaling cascades: RAS-MAPK, PI3K-Akt, and STAT pathways. Together, these pathways control gene transcription, cell cycle progression, cell proliferation and survival, adhesion, angiogenesis, and cell migration. To suppress EGFR-dependent signaling, two classes of EGFR antagonists have been developed. First, anti-EGFR monoclonal antibodies bind specifically to the extracellular domain of the receptor and inhibit ligand binding, thus preventing ligand-induced EGFR activation. Second, small-molecule EGFR tyrosine kinase inhibitors bind to the intracellular catalytic domain of the receptor, thereby, inhibiting EGFR tyrosine phosphorylation and downstream signaling pathways

an extracellular domain that recognizes and binds ligands specifically, such as epidermal growth factor (EGF), transforming growth factor (TGF)- $\alpha$ and amphiregulin which bind specifically to EGFR; (2) a hydrophobic transmem- brane domain that is involved in interactions between cell surface receptors; and (3) an intracellular domain that serves as a site of tryosine kinase activity. There are at least two exceptions to these general principles: HER2 has no known ligand and is constitutively active, and HER3 does not possess intrinsic tyrosine kinase activity. However, all receptors and their specific ligands interact to form an integrated system in which an initial signal can be amplified and diversified into multiple cellular responses.

To activate the EGFR signaling system, three sequential steps are generally required. First, specific ligands bind to the extracellular domain of EGFR, resulting in a conformational change. Second, this structural change allows the receptor to form a dimer with another ligand-bound EGFR (homodimer) or with one of the EGFR-related HER receptors (heterodimer). Finally, receptor dimerization causes autophosphorylation of tyrosine kinase residues within the intracellular domain of the receptors, leading to activation of signal transduction pathways. EGFR tyrosine phosphorylation triggers several signaling cascades, including the RAS-MAPK, PI3K-Akt and STAT pathways (Fig. 1b). Together, these EGFR-induced signaling pathways control gene transcription, cell cycle progression, cell proliferation and survival, adhesion, angiogenesis, migration, and invasion [14].

Activation of downstream signaling pathways without the involvement or modulation of cell surface receptors is another mechanism by which tumor cells can lose their dependence on growth factors. Perturbations in the EGFR signaling system may lead to the same effects as modulation of the EGFR alone: uncontrolled cell growth and proliferation, suppression of apoptosis, stimulation of angiogenesis, and increased metastatic spread (Fig. 1a). Consequently, the EGFR axis is thought to play a central role in the regulation of epithelial tumor cell growth, proliferation, and malignant transformation.

\section{EGFR-blocking therapy}

Given the important role of EGFR in tumorigenesis and disease progression, this receptor has become a relevant and promising target for anti-cancer therapies. In vitro and in vivo studies show that blocking EGFR and downstream signaling may lead to inhibition of carcinoma cell growth, resulting in potential benefits for cancer patients.

Two classes of EGFR antagonists have been developed and are currently used in cancer treatment (Fig. 1b). First, anti-EGFR monoclonal antibodies bind to the extracellular domain of the EGFR and compete with natural ligands for binding to the receptor, thus, blocking ligand-induced EGFR activation. Second, small-molecule inhibitors of EGFR tyrosine kinases compete with ATP for binding to the intracellular catalytic domain of the EGFR 
tyrosine kinase. This competition inhibits EGFR tyrosine phosphorylation and hence suppresses downstream signaling pathways.

Two anti-EGFR antibodies (cetuximab and panitumumab) and two small-molecule EGFR tyrosine kinase inhibitors (gefitinib and erlotinib) have been evaluated extensively for the treatment of colorectal cancer, metastatic non-small-cell lung cancer, squamous-cell carcinoma of the head and neck, and pancreatic cancer where malignant transformation depends on EGFR signaling [12]. Additional EGFR-targeting agents, including monoclonal antibodies, small molecules and vaccines, are currently under investigation [15].

\section{EGFR and colorectal cancer}

Several lines of evidence have demonstrated a role for EGFR in colorectal tumorigenesis. Preclinical data suggest that EGFR mRNA expression and EGF levels are higher in malignant areas of colorectal tumors than in the surrounding benign mucosa (as reviewed by Lockhart and Berlin [16]). In experimental models of colon cancer, TGF- $\alpha$ expression and EGFR activation allow for increased tumor cell growth and survival [16]. Moreover, mice treated with EGFR tyrosine kinase inhibitors and mice deficient in EGFR develop fewer colorectal polyps compared with untreated and wild-type mice, respectively, after challenge with colon cancer-inducing agents [16].

In human colorectal cancer, EGFR is also associated with tumor development and progression. The mechanisms underlying the role of EGFR in colorectal cancer are not entirely clear. EGFR is overexpressed in up to $82 \%$ of colorectal cancers [6-10]. EGFR amplification, preferentially of a mutant allele, is correlated with but does not reliably predict EGFR overexpression [17]. Mutations in the EGFR gene are rare in colorectal cancer but occur regularly in other cancer types, such as lung cancer [18-21].

Based on the importance of the EGFR axis in colorectal cancer, drugs that interfere with various functional domains of the receptor have been developed, as mentioned above. Currently, two anti-EGFR monoclonal antibodies have been approved in several countries for the treatment of colorectal cancer $[12,22]$. Cetuximab, a human-mouse chimeric IgG1 monoclonal antibody, was the first EGFR-targeted agent approved for the treatment of colorectal cancer [12, 23]. Panitumumab, a fully human IgG2K monoclonal antibody, was recently approved in the US and Europe as third-line treatment of metastatic colorectal cancer [12, 24]. Both antibodies have been shown to reduce the risk of tumor progression and to improve overall survival (OS), progression-free survival (PFS) and quality of life in patients with refractory colorectal cancer [11, 23, 25-28]. However, only a small proportion $(8-23 \%)$ of patients were observed to achieve an objective response with cetuximab [11, 23, 25] or panitumumab $[26,28]$. Cetuximab or panitumumab therapy is costly and might cause side effects. To optimize benefits and reduce the risks as well as contain costs associated with anti-EGFR treatment, the EGFR has been evaluated as a potential marker of clinical outcomes.

EGFR overexpression is more common among tumors of more advanced stage, tumors with worse histological grades, and tumors with lymphovascular invasion [7, 29, 30]. Patients with colorectal carcinomas showing EGFR staining by immunohistochemistry (IHC) in $>50 \%$ of tumor cells have a poor prognosis [8]. High EGFR expression correlates with lower response rates in patients with advanced rectal cancer undergoing preoperative radiotherapy [31]. These findings suggest that EGFR overexpression is associated with advanced disease, increased metastatic ability and poor prognosis, although its impact on patient survival is less conclusive [10]. However, these data came largely from studies in which colorectal cancer patients with refractory and/or metastatic disease were selected for anti-EGFR therapy on the basis of an EGFR-positive status. It is likely, with this selection bias in the population tested, that the frequency of EGFR overexpression and its relationship to colorectal cancer prognosis might have been overestimated in the literature thus far. Inter-laboratory variation in the detection of EGFR levels also contributed to uncertainty regarding the robustness of previous conclusions. Different methods for assessing EGFR expression have produced different results which may or may not correlate with tumor stage, metastatic potential, and patient outcome. There are also divergent EGFR expression patterns between primary and metastatic tumors, regardless of the testing method used. Taken together, the role of EGFR overexpression in colorectal cancer remains inconclusive and warrants further investigation.

While EGFR overexpression is common among colorectal tumors, several studies have shown that EGFR levels are a poor predictor of response to anti-EGFR therapies. In clinical trials evaluating the efficacy of cetuximab, treatment response was not related to levels of EGFR expression [11, 25, 28]. Cetuximab has shown efficacy in some patients with tumors negative for EGFR as assessed by IHC [32], while many patients with EGFR-expressing colorectal tumors fail to respond to cetuximab [11, 25]. Similarly, a number of patients with EGFR-expressing tumors do not benefit from panitumumab therapy [26-28]. More recently, increased EGFR gene copy number as detected by fluorescence in situ hybridization (FISH) was associated with response to cetuximab or panitumumab [33]. This has been contradicted by findings that FISH analysis of EGFR amplification does not select all colorectal cancer patients who may benefit from cetuximab therapy [34]. These discrepancies could be explained by 
tumor heterogeneity, presence of heterogeneous EGFR populations with different levels of low- and high-affinity sites, lack of standardized EGFR testing methods, and poor correlation between EGFR protein and DNA levels [17, 35].

The EGFR gene is rarely mutated in colorectal cancer. Less than $1 \%$ of colorectal carcinomas show mutations in the EGFR gene, according to the Cosmic database on somatic mutations in cancer (www.sanger.ac.uk/genetics/ $\mathrm{CGP} /$ cosmic/). For these reasons, EGFR mutations have limited to no prognostic power and also do not predict EGFR-targeted treatment outcomes in patients with colorectal cancer [19]. In non-small-cell lung cancer, however, EGFR mutations and gene amplification are closely linked with favorable response to small-molecule tyrosine kinase inhibitors [18, 20, 21, 36]. Of note, a recent study reported a strong correlation between EGFR mutation status and phosphorylation of the EGFR at tyrosine 992 (pEGFRtyr992) as detected by IHC [37]. Importantly, the expression of pEGFR-tyr992 also correlates significantly with clinical responsiveness to gefitinib in pulmonary adenocarcinoma [37]. It remains to be determined if this approach using specific antibodies recognizing EGFR phosphorylated forms can predict responses to anti-EGFR therapies in colorectal carcinoma.

\section{Biomarkers in colorectal cancer}

A major challenge in selecting appropriate patients for treatment is to identify reliable biomarkers that can predict the outcome of anti-EGFR therapies. As discussed above, EGFR protein expression, gene amplification, and mutations have limited predictive value in colorectal cancer, although they remain useful markers of treatment response in lung cancer $[10,13,18]$. The search for predictive biomarkers in colorectal cancer is now directed mainly toward key signaling components downstream of the EGFR.

Potential markers of alterations in EGFR-induced signaling in colorectal cancer include mutations in $K R A S$, $B R A F$, and PIK3CA genes as well as PTEN protein expression. The role of KRAS mutations, which result in constitutive activation of downstream EGFR signaling pathways, as a determinant of colorectal cancer prognosis and treatment response is discussed below.

Mutations in the BRAF gene, which encodes a serine/ threonine kinase that activates the RAS-MAPK pathway, have been found in $4-15 \%$ of colorectal cancers [38-40]. This frequency increases to $70 \%$ in colorectal cancers with a microsatellite instability (MSI) phenotype due to hypermethylation of the $M L H 1$ promoter [41-43]. In MSI colorectal carcinoma, $B R A F$ mutations occur independently of $K R A S$ mutations and provide proliferation and survival signals through activation of several signaling pathways [44, 45]. Cell lines with $R A S / B R A F$ mutations are highly resistant to cetuximab in vitro compared with wild-type cells [46]. One study showed no relationship between $B R A F$ mutations and median survival of patients with metastatic colorectal cancer receiving bevacizumab, an antibody against vascular endothelial growth factor-A (VEGF) [47]. However, there are no data available on the role of $B R A F$ mutations in predicting clinical response to anti-EGFR agents. Lievre et al. screened 30 colorectal cancer patients receiving cetuximab for several mutations including $B R A F$, but none of these patients had a tumor with a $B R A F$ mutation or a MSI phenotype [48].

The PIK3CA gene encodes the $110 \alpha$ catalytic subunit of phosphoinositide 3-kinase (PI3K) protein, a critical component of the PI3K-Akt signaling pathway downstream of ligand-induced EGFR activation (see Fig. 1b). This catalytic subunit can be activated by an interaction with RAS proteins. PIK3CA mutations have been found in 10 $18 \%$ of colorectal cancers $[38,46,49]$, but it is unclear whether these mutations can predict response to EGFRtargeted therapies. According to one in vitro study, cell lines with activating PIK3CA mutations are resistant to cetuximab compared with wild-type cell lines [46]. However, two studies failed to observe a link between PIK3CA mutation status and cetuximab response in patients with colon cancer $[33,48]$. These data were based on only five patients with PIK3CA mutations, possibly precluding the ability to find a significant link between PIK3CA mutations and treatment response. The predictive value of PIK3CA mutations in colorectal cancer needs to be clarified in larger studies.

PTEN (phosphatase and tensin homolog) acts as a tumor suppressor protein by inhibiting the PI3K-Akt signaling pathway (see Fig. 1b). Cell lines deficient in PTEN expression are more resistant to cetuximab in vitro than those with normal PTEN expression [46]. The loss of PTEN protein expression negatively predicts efficacy of cetuximab therapy in patients with metastatic colorectal cancer [50]. In this study, 63\% (10/16) of patients with tumors that showed normal PTEN expression were able to achieve a partial response whereas no response was documented in 11 patients with tumors that lacked PTEN expression [50]. Additional studies are warranted to evaluate PTEN as a marker in the selection of colorectal cancer patients for anti-EGFR therapies.

\section{KRAS: a downstream target of EGFR signaling}

The human KRAS oncogene is mutated in over $30 \%$ of colorectal cancers [51]. Over 3,000 KRAS point mutations in colorectal cancer have been reported thus far (www. sanger.ac.uk/genetics/CGP/cosmic/). Somatic missense 
mutations in the KRAS gene lead to single amino acid substitutions and are generally independent of $E G F R$ mutations [52]. The most frequent alterations are detected in codons $12(\sim 82 \%$ of all reported KRAS mutations) and $13(\sim 17 \%)$ in exon 2 of the KRAS gene. Mutations in other positions, such as codons 61 and 146, have also been reported [51]. However, these alterations account for a minor proportion $(1-4 \%)$ of KRAS mutations and their clinical relevance in colorectal cancer is unclear [51, 53]. KRAS mutations in codons 12 and 13 appear to play a major role in the progression of colorectal cancer [54-56], while mutations in codons 12,13 , and 61 are potential biomarkers in lung cancer [57].

The KRAS gene encodes a small G-protein that functions downstream of EGFR-induced cell signaling. This Gprotein belongs to the family of RAS proteins that are involved in coupling signal transduction from cell surface receptors to intracellular targets via several signaling cascades, including the RAS-MAPK pathway (Fig. 1b). RAS proteins normally cycle between active GTP-bound (RAS-GTP) and inactive GDP-bound (RAS-GDP) conformations (see Fig. 3). RAS proteins are activated by guanine nucleotide exchange factors (GEFs) which are recruited to protein complexes at the intracellular domain of activated receptors. Signaling is terminated when RAS-GTP is hydrolyzed to the RAS-GDP inactive complex by GTPase-activating proteins (GAPs). Under physiological conditions, levels of RAS-GTP in vivo are tightly controlled by the counterbalancing activities of GEFs and GAPs. Mutations in genes that encode RAS proteins disrupt this balance, causing perturbations in downstream signaling activities.

KRAS mutations result in RAS proteins that are permanently in the active GTP-bound form (Fig. 2) due to defective intrinsic GTPase activity and resistance to GAPs. Unlike wild-type RAS proteins which are inactivated after a short time, the aberrant proteins are able to continuously activate signaling pathways in the absence of any upstream stimulation of EGFR/HER receptors. Oncogenic activation of RAS signaling pathways has been implicated in many aspects of the malignant process, including abnormal cell growth, proliferation, and differentiation. KRAS mutations are, in most cases, an early event in the development and progression of colorectal cancers [56, 58, 59]. Consistent with this concept, several studies have demonstrated that KRAS mutation status is an important prognostic factor in colorectal cancer [55, 58-60]. KRAS mutations are associated with tumors of more advanced stage, increased metastatic potential, poor prognosis, and decreased PFS and OS of patients $[55,56,58,59]$. The prognostic value of $K R A S$ mutations in colorectal cancer is presently controversial and warrants further confirmation.

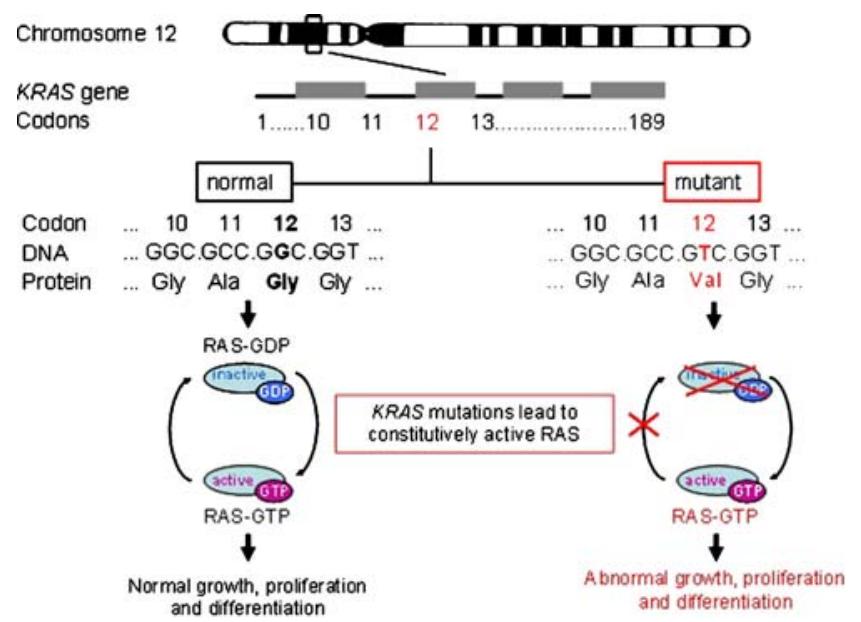

Fig. 2 Role of KRAS mutations in oncogenic activation of intracellular signaling. The human $K R A S$ gene, located on chromosome 12, encodes a small G-protein that functions downstream of EGFRinduced cell signaling. This G-protein belongs to the family of RAS proteins involved in signal transduction pathways that regulate cell development and function. RAS proteins normally cycle between active (RAS-GTP) and inactive (RAS-GDP) conformations. Somatic missense mutations in codon 12 of the KRAS gene, leading to single amino acid substitutions such as p.Gly12Val, are the most common alterations found in colorectal tumors. These KRAS mutations result in RAS proteins that are constitutively in the active RAS-GTP conformation. Unlike wild-type RAS proteins which are deactivated after a short time, the mutated RAS proteins cause continuous activation of RAS signaling pathways in the absence of upstream stimulation of EGFR/HER receptors. This oncogenic activation of RAS signaling pathways leads to abnormal cell growth, proliferation and differentiation

KRAS mutation status may have a considerable impact on therapeutic decisions for colorectal cancer patients. Considering the molecular basis of EGFR-targeting agents, blocking EGFR at the receptor level will not ablate downstream signaling activities in tumors with KRAS mutations and hence constitutively active RAS proteins. Indeed, several studies have reported that KRAS mutations confer resistance to anti-EGFR monoclonal antibodies [24, 48, 61-65]. KRAS mutations are associated with poor responses to therapy, reduced PFS and shorter OS in colorectal cancer patients treated with cetuximab alone or in combination with chemotherapy [48, 62-65]. Similarly, an analysis of KRAS mutations in tumor samples from $92 \%$ of patients in a registrational clinical trial of panitumumab for the treatment of metastatic colorectal cancer predicted a lack of efficacy of panitumumab on PFS and OS in patients with KRAS mutant tumors [24]. Taken together, these results indicate that KRAS mutation status is an important parameter for selecting patients for therapy: patients with mutant tumors will not benefit from EGFR-targeted therapies. On the basis of these data, the European Medicines Agency (EMEA) has approved the use of cetuximab and panitumumab for the treatment of metastatic 
colorectal cancer in patients who carry a normal, wild-type $K R A S$ gene [12]. However, as only a fraction of patients with colorectal tumors that carry a wild-type $K R A S$ allele can achieve a clinical response with EGFR-targeted therapies, the search for additional predictive parameters remains an important challenge.

\section{Methods for KRAS mutation testing}

PCR has become the cornerstone of molecular diagnostic tools, including those developed for KRAS mutation testing. PCR assays are highly sensitive and can be easily automated. PCR assays are thus well-suited for large-scale, high-throughput diagnostic testing. For KRAS mutation testing, however, standard PCR assays are not sufficient. The main requirement for conclusive $K R A S$ genotyping by PCR assay is the ability to discriminate between different mutant alleles and wild type. There are two main challenges to achieving a conclusive result: one is the heterogeneity of the testing material, and the other is differences in the detection limits for distinct mutations. Depending on the tissue analyzed, the amount of tumor versus non-tumor area is variable and heterogeneous, resulting in a template mixture in which wild-type and mutant DNA are not present in equimolar amounts. Moreover, a cancer cell may carry a heterozygous or homozygous KRAS mutation, increasing the genetic heterogeneity of the tissue material used. Differences in PCR efficiencies for the detection of the different mutations can lead to a bias whereby certain mutations are detected preferentially over others.

A plethora of methods is available for the detection of mutations in the KRAS gene (see Table 1 for a nonexhaustive overview). Many of these methods are laboratory-based assays and are not commercially available for use in routine diagnostics. Other methods have been developed further and are available as commercial test kits not directly intended for diagnostic purposes. To date, two KRAS mutation test kits (TheraScreen ${ }^{\circledR}$ by DxS Ltd. and KRAS LightMix ${ }^{\circledR}$ by TIB MolBiol) have met the essential requirements of the relevant European Directives (CEMark) for diagnostic use in the European Union. Only one study, to our knowledge, has evaluated the concordance between different methods for KRAS mutation testing [66]. In this study, 40 colorectal tumor samples were tested for seven common mutations in codons 12 and 13 of the KRAS gene by four commercially available assays and by direct sequencing as a reference. Two allele-specific PCRbased methods and one PCR/direct sequencing method demonstrated high to good agreement with direct sequencing, whereas an oligonucleotide hybridization method showed poor agreement. Given the technical requirements for a conclusive KRAS test result and the potential for variability between different KRAS genotyping methods, a thorough analytical validation of testing methods together with a high standard of quality assurance are critical for accurate, reliable KRAS mutation testing in clinical practice. Such an initiative to validate and standardize KRAS mutation testing will also include the development of a website (http://esp-pathology.org) providing the latest information on current diagnostic methods and intended uses of KRAS mutation testing. Therefore, at present, no advice is given to which method is preferred. The advantage of commercially available tests is the validation process that these have gone through, but obviously the costs of these tests are higher that in-house developed methods. Most experience exists in different laboratories with sequencing after PCR, and this is a relatively inexpensive method, but requires validation on a large series of cases. For most other methods, it is too early to assess the advantages and disadvantages.

\section{Recommended guidelines and European QA program}

Guidelines for $K R A S$ mutation testing in colorectal cancer

The optimal use of EGFR-targeted therapies requires accurate KRAS mutation testing. Testing for KRAS mutations generally comprises three stages: (1) referral for $K R A S$ mutation testing; (2) selection of the tissue block containing the tumor area of interest; and (3) DNA extraction and KRAS mutation analysis. In the current clinical setting, colorectal cancer patients are not routinely screened for KRAS mutation status. Pathologists test for KRAS mutations only upon the specific request of a clinician. Clinicians, in turn, request KRAS genotyping only if the test results are intended to guide decisions on patient management. These practices might not be sufficient for optimal patient care. The process of requesting KRAS status testing, finding the original tissue block and reporting the test results is cumbersome, time-consuming, and prone to errors. Therefore, routine mutation testing at the time of initial diagnosis of stage II and III tumors should be considered. There is also a lack of validated testing methods and standardized operating procedures for the detection of KRAS mutations. There are very few studies that have systematically compared the sensitivity, specificity and reproducibility of the different techniques for KRAS genotyping. The concordance between different diagnostic methods is also largely unknown. Therefore, there is an urgent need to establish and implement clinical practice guidelines and standardized procedures for KRAS mutation testing in patients with colorectal cancer.

In recognition of the importance of accurate HER2 testing in breast cancer management, practice guidelines 
Table 1 Overview of methods used for KRAS genotyping

\begin{tabular}{|c|c|c|}
\hline Method & Intended use & Ref. \\
\hline \multicolumn{3}{|l|}{ Gel electrophoresis assays } \\
\hline Temporal temperature gradient electrophoresis & LBM & {$[67]$} \\
\hline Denaturing gradient gel electrophoresis & LBM & {$[68]$} \\
\hline Constant denaturant capillary electrophoresis & LBM & {$[69]$} \\
\hline SSCP assay & LBM & {$[70]$} \\
\hline \multicolumn{3}{|l|}{ Sequencing } \\
\hline Dideoxy sequencing & LBM, RUO kit & [71] \\
\hline Pyrosequencing & LBM & {$[72,73]$} \\
\hline PyroMark $^{\mathrm{TM}} K R A S$ & RUO kit & \\
\hline \multicolumn{3}{|l|}{ Allele-specific PCR assays ${ }^{a}$} \\
\hline \multicolumn{3}{|l|}{ Allele discrimination based on primer design } \\
\hline ARMS-PCR & LBM & {$[74,75]$} \\
\hline$K R A S$ mutation test kit & RUO kit & \\
\hline TheraScreen ${ }^{\circledR}$ kit & CE-Mark kit for clinical use & {$[76]$} \\
\hline$K R A S$ LightMix ${ }^{\circledR}$ kit & CE-Mark kit for clinical use & \\
\hline REMS-PCR & LBM & {$[77]$} \\
\hline FLAG assay & LBM & [78] \\
\hline Enriched PCR-RFLP & LBM & [79] \\
\hline \multicolumn{3}{|c|}{ Allele discrimination based allele-specific ligation detection reaction } \\
\hline PCR-LDR & LBM & {$[80]$} \\
\hline PCR-LDR spFRET assay & LBM & {$[81]$} \\
\hline \multicolumn{3}{|c|}{ Allele discrimination based on discriminating amplification efficiencies at low melting temperatures } \\
\hline COLD-PCR & LBM & {$[82]$} \\
\hline \multicolumn{3}{|l|}{ Other methods } \\
\hline Surface ligation reaction and biometallization & LBM & [83] \\
\hline Multi-target DNA assay panel & LBM & [84] \\
\hline \multicolumn{3}{|c|}{ Allele-specific oligonucleotide hybridization - Invigene ${ }^{\circledR}$} \\
\hline$K R A S$ genotyping kit & LBM, RUO kit & \\
\hline
\end{tabular}

LBM Laboratory-based method, not commercially available, RUO: research use only, not validated for clinical applications

${ }^{\text {a }}$ Allele-specific assays are also used by vendors offering KRAS genotyping services

and a testing algorithm for HER2 testing have been formulated by the American Society of Clinical Oncology and the College of American Pathologists [3]. This expert panel has recommended validation of all laboratory assays or modifications, use of standardized operating procedures, and compliance with new testing criteria. Importantly, the panel has also recommended that HER2 testing be done in an accredited laboratory or in a laboratory that meets the quality assurance and proficiency requirements set forth in the practice guidelines.

To address the need for standardized KRAS mutation testing methods and procedures in colorectal carcinoma, two working groups of the European Society of Pathology (ESP), the Diseases of the Digestive Tract ESP Working Group and the Molecular Pathology ESP Working Group, convened an expert panel to develop guideline recommendations and a proposal for a European QA program for KRAS mutation testing. This expert panel consisted of European pathologists, molecular biologists, and oncologists with expertise in colorectal carcinoma and $K R A S$ mutation analysis. A panel meeting was held during the
Third Intercontinental Congress of Pathology in Barcelona in May 2008. The purpose of this meeting was for the panel members to refine and agree on draft guidelines and an organizational structure of a European QA program for $K R A S$ mutation testing. Consensus recommendations and proposals are summarized here.

\section{Target patient population for KRAS mutation testing}

Activating mutations in codons 12 and 13 of the KRAS gene identify patients who have a poor clinical response to EGFR-targeted therapies. Ideally, a predictive test should distinguish between treatment responders and non-responders accurately and reliably. Such an ideal predictor is presently not available. The best option available today is a test that identifies patients who carry two wild-type KRAS alleles and excludes patients with mutant codon 12 or 13 alleles.

The anti-EGFR antibodies, cetuximab and panitumumab, currently available for clinical use have been approved in several countries for the treatment of patients 
with $K R A S$ wild-type metastatic colorectal cancer. In the European Union, cetuximab has been approved for use in combination with chemotherapy or as a single agent in patients who are refractory or intolerant to irinotecan-based chemotherapy. Similarly, panitumumab has been approved as third-line treatment for refractory metastatic colorectal cancer. Routine testing for KRAS mutations might not be beneficial for patients with stage I colorectal carcinoma. However, this expert panel recommends standard KRAS mutation testing for all patients with stage II to III colorectal carcinomas.

\section{The role of the primary pathologist in KRAS mutation testing}

The primary pathologist plays a central role in KRAS mutation testing. The pathologist can either perform the test at his/her laboratory if it has been accredited for KRAS mutation testing or send the tissue block to a reference laboratory for external testing. In both situations, the pathologist is responsible for at least three important procedures. First, the pathologist is responsible for choosing the most appropriate tissue block to be tested (see below for discussion on optimal material for testing). Second, the pathologist should ensure that the tissue block selected for KRAS genotyping contains sufficient quantity of invasive tumor cells needed for analysis. The minimum amount of tumor versus non-tumor area required will depend on the KRAS genotyping method. It is the pathologist's responsibility to evaluate the tumor content of the tissue block and to ensure that it fulfills the minimum criterion of the testing method. To evaluate tumor content, it is recommended that the pathologist assess a hematoxylin-eosin (HE) stained section of the tissue area of the paraffin block designated for DNA extraction and $K R A S$ mutation analysis before and after DNA extraction. This will ensure that the tissue area has an adequate tumor density, preferably greater than $70 \%$ invasive carcinoma cells, needed for detection of KRAS mutations. Finally, the pathologist is responsible for documentation, which should include results from HE staining analysis as well as from $K R A S$ mutation testing, and for preparation of the pathology report (see below on optimal reporting of KRAS test results). If the testing is performed by a reference laboratory, the pathologist should integrate the test results into the pathology report.

\section{Optimal tissue material for KRAS mutation testing}

Based on current knowledge, the most appropriate material for KRAS mutation testing is primary tumor tissue. This type of material is commonly archived and thus accessible, and typically contains sufficient amount of invasive carcinoma cells required for KRAS mutation testing. If an endoscopic biopsy of the primary tumor is performed, it is important that the material obtained contains adequate amount of adenocarcinoma cells in the area identified.

However, it is estimated that $20 \%$ of the target patient population will present with metastatic disease and will not have archival material from the primary tumor. This poses an important challenge for the pathologist in the selection of appropriate material for $K R A S$ mutation testing. In this situation, the panel recommends that KRAS mutation testing is performed using material from the metastatic tumor, for example, from resected liver metastases or positive lymph nodes. The pathologist must ensure that the metastatic tissue block contains adequate amount of adenocarcinoma cells.

For some patients, both the primary tumor tissue as well as metastatic tissue specimens might be available for KRAS mutation testing. At present, there are insufficient data available to demonstrate the superiority of either primary or metastatic tissue material for KRAS mutation testing. In the experience of this expert panel, primary and metastatic tumor tissues from the same patient can give discordant results on KRAS mutation status. However, the true discordance in KRAS genotyping results between primary and metastatic tumor tissues is presently unknown. More studies are needed to better define which type of material can provide the most reliable results in patients with metastatic disease. Until such data are available, the panel recommends that, in accordance with existing literature data, primary tumor tissue is tested, but that, ideally, both primary and metastatic tumor tissues are analyzed for $K R A S$ mutation status and that the results are collected in a central database to increase our knowledge. In case the results are discordant, presently no evidence is available to advise standard treatment and the patient needs to be discussed in a multidisciplinary team.

In general, a paraffin block containing only tissue from adenoma or non-invasive carcinoma should not be used for $K R A S$ mutation analysis. If an endoscopic biopsy of the primary tumor or a biopsy of a metastatic site is performed, the pathologist should ensure that malignant cells are present in the biopsy material to be tested and clearly indicate which blocks or slides should be used for testing.

\section{Optimal procedures for KRAS mutation testing}

To ensure accurate KRAS mutation testing, the panel recommends that each laboratory develops standardized operating procedures and testing requirements for $K R A S$ mutation analysis using available information that will be provided by either the vendors of a commercially available method or the ESP-website (see below). Recommendations for specific testing parameters, including method sensitivity 
and specificity, method validation, analysis success rate, and documentation of costs, are summarized in Table 2 . Some of these recommendations are compatible with ISO (International Organization for Standardization; http://www. iso.org) general requirements for the competence of testing and calibration laboratories (ISO/IEC 17025:2005). These requirements will become essential components of accreditation for KRAS mutation testing. Tests that have a detection sensitivity of $1 \%$ might detect subclones in a tumor that have acquired a mutation. It is presently unknown what the consequence of such a finding might be.

\section{Optimal reporting of test results}

Result reporting is an integral part of any diagnostic procedure, including KRAS mutation testing. All KRAS test results are to be reported to the primary pathologist who is responsible for preparation of the pathology report for a specific tissue block or biopsy material. Optimal reporting of KRAS test results should conform to the OECD Guidelines for Quality Assurance in Molecular Genetic Testing (http://www.oecd.org). In brief, the reports should include at minimum the following information: (1) identification of the patient and health care professional; (2) type of material and percentage of tumor cells present in the sample; (3) indication for testing and patient-specific medical data; (4) the testing method used, including its analytical sensitivity and specificity; and (5) test results (mutant or wild-type $K R A S$ allele) and interpretation of results in the context of the indication for testing.
Proposal for a European quality assurance program

During the process of developing a European QA program for KRAS mutation testing, the expert panel considered the experience with HER2 testing as an informative example. While trastuzumab (Herceptin ${ }^{\circledR}$ ) became available in 2002 for the treatment of breast cancer, it was another 5 years before clinical practice guidelines were established for optimal HER2 testing algorithm and proficiency requirements. Another problem encountered with the introduction of trastuzumab was the lack of adequate financial provisions for diagnostic testing, although some national authorities required mandatory HER2 testing in breast cancer patients prior to trastuzumab therapy. Today, molecular diagnostic tools, testing procedures and the reimbursement process for diagnostic tests linked to a specific medication differ greatly across countries in Europe. Clearly, there is a need to establish a standardized, evidence-based QA program for molecular diagnostics across the European Union.

Here, we propose to establish a European QA program for testing KRAS mutations in colorectal cancer. This program aims to ensure optimal accuracy and proficiency in KRAS mutation testing across all countries or institutions in the European Union. A potential framework for a European QA program for KRAS mutation testing is shown in Fig. 3. The program will be organized by the European Society of Pathology in close collaboration with existing regional and/or national QA programs. Laboratories can participate in the European QA program at the regional or

Table 2 Recommendations for $K R A S$ mutation testing

\begin{tabular}{ll}
\hline Parameter & Recommendation \\
\hline Sensitivity & The lower detection limit of mutant signal should be set at $1 \%$ of tumor cells for allele-specific PCR and $25-30 \%$ for direct \\
sequencing. & A specific test should be able to detect 7 common mutations in codons 12 and 13 of the $K R A S$ gene and not detect mutations \\
in codon 61. False negatives may occur because of test specificities (e.g. lack of an allele-specific PCR for codon 13 & \\
& mutation). \\
Method & The laboratory should use a validated method for $K R A S$ mutation testing. The objectives of the validation are to: \\
validation ${ }^{\text {a }}$ & Determine the minimum tumor tissue area and section thickness for DNA extraction. \\
& Stipulate which fixatives are acceptable for use. \\
& Determine input DNA quantity, quality and concentration. \\
& Determine the cut-off values for discerning $K R A S$ mutant alleles from wild-type alleles. \\
& Evaluate sensitivity of the test, for example by using dilution series cell lines. \\
& Compare the accuracy of test results against a pre-defined reference method (e.g. direct sequencing). \\
& Determine the reproducibility between different testing assays and equipment. \\
Verify the robustness of the testing method. Robustness may be influenced by several factors, including varying DNA & \\
Analysis & concentrations and the use of manual or automated protocols or equipment. \\
success rate & $95 \%$ laboratory should obtain the following success rates for accreditation: \\
Costs & $97 \%$ of samples with correct $K R A S$ test results \\
\hline
\end{tabular}

${ }^{\text {a }}$ Compatible with accreditation requirements of ISO/IEC 17025:2005 


\section{European Society of Pathology / European Quality Assurance (QA) Council}

\section{European Union level}

\section{European QA program coordinator for KRAS testing}

Mat alss ve letwont. aldparte EI ps

L lakses betwe eI Europe ai $Q A$ coucll ard regbial or ce itralbe d $Q A$ programs

DEt tb ites the est sampes to R gbialand $\propto$ ittate d plogians

Docime it the metiods isedaid test resi it fom partopating labolatorks

\section{Regional or centralized level}

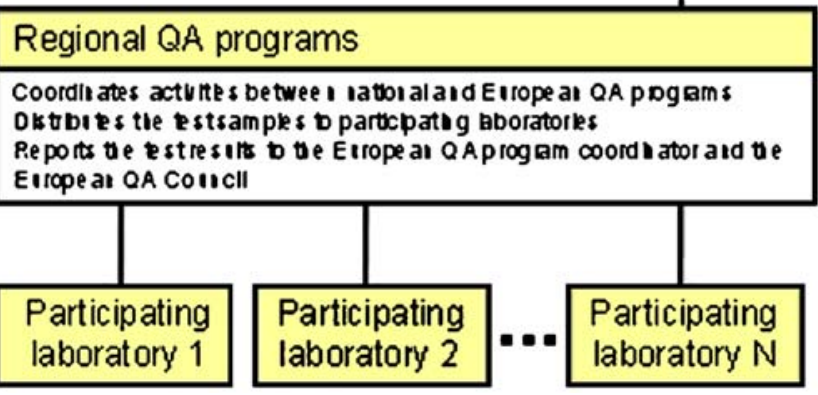

Fig. 3 Proposed framework for a European quality assurance (QA) program for $K R A S$ mutation testing in colorectal cancer. The European QA program, under the direction of a QA council, will be organized by the European Society of Pathology in close collaboration with existing regional and/or national QA programs. The QA program,

centralized level, depending on the country's specific circumstances. Laboratories in countries with existing QA programs may attain accreditation at the regional level, whereas a centralized program will be created to coordinate QA activities for countries or institutions not yet engaged in a QA program.

The fundamental initiatives of the proposed European QA program are as follows:

1. The European QA program for $K R A S$ mutation testing aims to provide timely, standardized, evidence-based guidelines for the performance of a diagnostic test for $K R A S$ mutations on colorectal tumor tissues.

2. The European QA program intends to collaborate with existing regional and/or national QA programs to develop strategies and standardized procedures that help to ensure optimal performance, interpretation and reporting of KRAS mutation analysis. To achieve this, the European QA program will provide administrative and logistic support and networking opportunities for the development and implementation of standardized operating procedures and QA criteria for proficiency testing and competency assessments. The European QA program will also coordinate accredita-

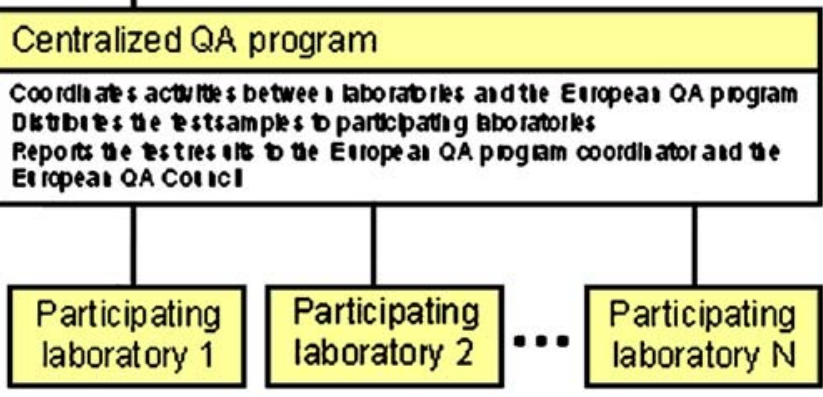

together with a designated coordinator, will be responsible for establishing QA guidelines and testing criteria, implementing the QA program and performing laboratory accreditation. Participating laboratories can attain accreditation at the regional or centralized level

tion of participating laboratories at the European and regional level.

3. The European QA program will facilitate the administrative process and reimbursement discussions in each country in the European Union by providing the necessary documents and QA schemes for implementation and performance of diagnostic tests for KRAS mutation analysis.

To support these proposed initiatives, the European QA program intends to establish and maintain a website (http:// esp-pathology.org) that will provide the latest recommendations, as well as, potentially, an overview of validated laboratory methods, standardized operating procedures, and accreditation criteria relevant for KRAS mutation testing.

As our understanding of the genetics and molecular biology of colorectal cancer advances, other parameters will hopefully be identified as predictors of treatment outcome. Presently, KRAS mutation status must be considered in the appropriate therapeutic context for each patient. The guideline recommendations and European QA program proposed here for KRAS mutation testing will help to ensure that all patients who may or may not benefit from EGFR-targeted therapies are identified in a timely and 
consistent manner. Although the proposed QA program is intended for the standardization of $K R A S$ mutation testing methods and procedures, this expert panel is of the opinion that such a program can potentially be adapted to incorporate other predictive biomarkers in colorectal cancer as they become available.

\section{Conclusions}

Colorectal cancer is a major cause of cancer-related mortality. The EGFR signaling pathway is frequently activated in colorectal cancer and has been extensively investigated as a target for cancer therapy. Therapeutic agents that target the EGFR have improved outcomes for patients with colorectal cancer, although they are effective in only a subset of patients. Point mutations in codons 12 and 13 of the KRAS oncogene are predictive of poor response to EGFR-targeted therapies. Testing for KRAS mutation status is, therefore, a potential strategy to select those patients who will or will not benefit from EGFRtargeted therapies. Although many robust techniques have been developed for KRAS genotyping, most of these techniques or testing procedures have not been validated in the clinical setting. Thus, there is an urgent need for validated methods and standardized testing procedures to ensure accurate testing of KRAS mutation status. Here we propose guideline recommendations and a European quality assurance program for $K R A S$ mutation testing in patients with colorectal carcinoma.

Acknowledgements The panel meeting held during the Third Intercontinental Congress of Pathology in Barcelona, May 2008 was supported by Amgen Inc.

G. Hoefler: Project GZ 70420/0134-IV/B/12/2006 “Molecular Markers To Predict Clinical Outcome and Therapy Response in Stage II Colon Cancer" of the Austrian Ministry for Health, Family and Youth.

Writing assistance was provided by Archimed medical communication ag, Zofingen, Switzerland.

Open Access This article is distributed under the terms of the Creative Commons Attribution Noncommercial License which permits any noncommercial use, distribution, and reproduction in any medium, provided the original author(s) and source are credited.

\section{References}

1. Owens MA, Horten BC, Da Silva MM (2004) HER2 amplification ratios by fluorescence in situ hybridization and correlation with immunohistochemistry in a cohort of 6,556 breast cancer tissues. Clin Breast Cancer 5:63-69

2. Dowsett M, Hanna WM, Kockx M, Penault-Llorca F, Ruschoff J, Gutjahr T, Habben K, van de Vijver MJ (2007) Standardization of HER2 testing: results of an international proficiency-testing ring study. Mod Pathol 20:584-591
3. Wolff AC, Hammond ME, Schwartz JN, Hagerty KL, Allred DC, Cote RJ, Dowsett M, Fitzgibbons PL, Hanna WM, Langer A, McShane LM, Paik S, Pegram MD, Perez EA, Press MF, Rhodes A, Sturgeon C, Taube SE, Tubbs R, Vance GH, van d V, Wheeler TM, Hayes DF (2007) American Society of Clinical Oncology/College of American Pathologists guideline recommendations for human epidermal growth factor receptor 2 testing in breast cancer. J Clin Oncol 25:118-145

4. Ellis IO, Coleman D, Wells C, Kodikara S, Paish EM, Moss S, Al-Sam S, Anderson N, Bobrow L, Buley I, Connolly CE, Dallimore NS, Hales S, Hanby A, Humphreys S, Knox F, Lowe J, Macartney J, Nash R, Parham D, Patnick J, Pinder SE, Quinn CM, Robertson AJ, Shrimankar J, Walker RA, Winder R (2006) Impact of a national external quality assessment scheme for breast pathology in the UK. J Clin Pathol 59:138-145

5. Jemal A, Siegel R, Ward E, Hao Y, Xu J, Murray T, Thun MJ (2008) Cancer statistics, 2008. CA Cancer J Clin 58:71-96

6. Hemming AW, Davis NL, Kluftinger A, Robinson B, Quenville NF, Liseman B, LeRiche J (1992) Prognostic markers of colorectal cancer: an evaluation of DNA content, epidermal growth factor receptor, and Ki-67. J Surg Oncol 51:147-152

7. Kluftinger AM, Robinson BW, Quenville NF, Finley RJ, Davis NL (1992) Correlation of epidermal growth factor receptor and c-erbB2 oncogene product to known prognostic indicators of colorectal cancer. Surg Oncol 1:97-105

8. Mayer A, Takimoto M, Fritz E, Schellander G, Kofler K, Ludwig H (1993) The prognostic significance of proliferating cell nuclear antigen, epidermal growth factor receptor, and mdr gene expression in colorectal cancer. Cancer 71:2454-2460

9. Salomon DS, Brandt R, Ciardiello F, Normanno N (1995) Epidermal growth factor-related peptides and their receptors in human malignancies. Crit Rev Oncol Hematol 19:183-232

10. Spano JP, Lagorce C, Atlan D, Milano G, Domont J, Benamouzig R, Attar A, Benichou J, Martin A, Morere JF, Raphael M, Penault-Llorca F, Breau JL, Fagard R, Khayat D, Wind $P$ (2005) Impact of EGFR expression on colorectal cancer patient prognosis and survival. Ann Oncol 16:102-108

11. Saltz LB, Meropol NJ, Loehrer PJ Sr, Needle MN, Kopit J, Mayer RJ (2004) Phase II trial of cetuximab in patients with refractory colorectal cancer that expresses the epidermal growth factor receptor. J Clin Oncol 22:1201-1208

12. Ciardiello F, Tortora G (2008) EGFR antagonists in cancer treatment. N Engl J Med 358:1160-1174

13. Metro G, Finocchiaro G, Cappuzzo F (2006) Anti-cancer therapy with EGFR inhibitors: factors of prognostic and predictive significance. Ann Oncol 17 Suppl 2:ii42-ii45

14. Harari PM, Allen GW, Bonner JA (2007) Biology of interactions: antiepidermal growth factor receptor agents. J Clin Oncol 25:4057-4065

15. Ono M, Kuwano M (2006) Molecular mechanisms of epidermal growth factor receptor (EGFR) activation and response to gefitinib and other EGFR-targeting drugs. Clin Cancer Res 12:7242-7251

16. Lockhart AC, Berlin JD (2005) The epidermal growth factor receptor as a target for colorectal cancer therapy. Semin Oncol 32:52-60

17. Spindler KL, Lindebjerg J, Nielsen JN, Olsen DA, Bisgard C, Brandslund I, Jakobsen A (2006) Epidermal growth factor receptor analyses in colorectal cancer: a comparison of methods. Int J Oncol 29:1159-1165

18. Bonomi PD, Buckingham L, Coon J (2007) Selecting patients for treatment with epidermal growth factor tyrosine kinase inhibitors. Clin Cancer Res 13:s4606-s4612

19. Ogino S, Meyerhardt JA, Cantor M, Brahmandam M, Clark JW, Namgyal C, Kawasaki T, Kinsella K, Michelini AL, Enzinger PC, Kulke MH, Ryan DP, Loda M, Fuchs CS (2005) Molecular alterations in tumors and response to combination chemotherapy 
with gefitinib for advanced colorectal cancer. Clin Cancer Res 11:6650-6656

20. Paez JG, Janne PA, Lee JC, Tracy S, Greulich H, Gabriel S, Herman P, Kaye FJ, Lindeman N, Boggon TJ, Naoki K, Sasaki H, Fujii Y, Eck MJ, Sellers WR, Johnson BE, Meyerson M (2004) EGFR mutations in lung cancer: correlation with clinical response to gefitinib therapy. Science 304:1497-1500

21. Pao W, Miller V, Zakowski M, Doherty J, Politi K, Sarkaria I, Singh B, Heelan R, Rusch V, Fulton L, Mardis E, Kupfer D, Wilson R, Kris M, Varmus H (2004) EGF receptor gene mutations are common in lung cancers from "never smokers" and are associated with sensitivity of tumors to gefitinib and erlotinib. Proc Natl Acad Sci U S A 101:13306-13311

22. Rocha-Lima CM, Soares HP, Raez LE, Singal R (2007) EGFR targeting of solid tumors. Cancer Control 14:295-304

23. Jonker DJ, O'Callaghan CJ, Karapetis CS, Zalcberg JR, Tu D, Au HJ, Berry SR, Krahn M, Price T, Simes RJ, Tebbutt NC, van HG, Wierzbicki R, Langer C, Moore MJ (2007) Cetuximab for the treatment of colorectal cancer. N Engl J Med 357:2040-2048

24. Amado RG, Wolf M, Peeters M, Van CE, Siena S, Freeman DJ, Juan T, Sikorski R, Suggs S, Radinsky R, Patterson SD, Chang DD (2008) Wild-type KRAS is required for panitumumab efficacy in patients with metastatic colorectal cancer. J Clin Oncol 26:16261634

25. Cunningham D, Humblet Y, Siena S, Khayat D, Bleiberg H, Santoro A, Bets D, Mueser M, Harstrick A, Verslype C, Chau I, Van CE (2004) Cetuximab monotherapy and cetuximab plus irinotecan in irinotecan-refractory metastatic colorectal cancer. $\mathrm{N}$ Engl J Med 351:337-345

26. Gibson TB, Ranganathan A, Grothey A (2006) Randomized phase III trial results of panitumumab, a fully human anti-epidermal growth factor receptor monoclonal antibody, in metastatic colorectal cancer. Clin Colorectal Cancer 6:29-31

27. Siena S, Peeters M, Van CE, Humblet Y, Conte P, Bajetta E, Comandini D, Bodoky G, van HG, Salek T, Wolf M, Devercelli G, Woolley M, Amado RG (2007) Association of progression-free survival with patient-reported outcomes and survival: results from a randomised phase 3 trial of panitumumab. Br J Cancer 97:14691474

28. Van CE, Peeters M, Siena S, Humblet Y, Hendlisz A, Neyns B, Canon JL, Van Laethem JL, Maurel J, Richardson G, Wolf M, Amado RG (2007) Open-label phase III trial of panitumumab plus best supportive care compared with best supportive care alone in patients with chemotherapy-refractory metastatic colorectal cancer. J Clin Oncol 25:1658-1664

29. Radinsky R, Risin S, Fan D, Dong Z, Bielenberg D, Bucana CD, Fidler IJ (1995) Level and function of epidermal growth factor receptor predict the metastatic potential of human colon carcinoma cells. Clin Cancer Res 1:19-31

30. Steele RJ, Kelly P, Ellul B, Eremin O (1990) Epidermal growth factor receptor expression in colorectal cancer. Br J Surg 77:1352-1354

31. Giralt J, Eraso A, Armengol M, Rossello J, Majo J, Ares C, Espin $\mathrm{E}$, Benavente S, de T I (2002) Epidermal growth factor receptor is a predictor of tumor response in locally advanced rectal cancer patients treated with preoperative radiotherapy. Int J Radiat Oncol Biol Phys 54:1460-1465

32. Chung KY, Shia J, Kemeny NE, Shah M, Schwartz GK, Tse A, Hamilton A, Pan D, Schrag D, Schwartz L, Klimstra DS, Fridman D, Kelsen DP, Saltz LB (2005) Cetuximab shows activity in colorectal cancer patients with tumors that do not express the epidermal growth factor receptor by immunohistochemistry. J Clin Oncol 23:1803-1810

33. Moroni M, Veronese S, Benvenuti S, Marrapese G, Sartore-Bianchi A, Di NF, Gambacorta M, Siena S, Bardelli A (2005) Gene copy number for epidermal growth factor receptor (EGFR) and clinical response to
antiEGFR treatment in colorectal cancer: a cohort study. Lancet Oncol 6:279-286

34. Italiano A, Follana P, Caroli FX, Badetti JL, Benchimol D, Garnier G, Gugenheim J, Haudebourg J, Keslair F, Lesbats G, Lledo G, Roussel JF, Pedeutour F, Francois E (2008) Cetuximab shows activity in colorectal cancer patients with tumors for which FISH analysis does not detect an increase in EGFR gene copy number. Ann Surg Oncol 15:649-654

35. Francoual M, Etienne-Grimaldi MC, Formento JL, Benchimol D, Bourgeon A, Chazal M, Letoublon C, Andre T, Gilly N, Delpero JR, Lasser P, Spano JP, Milano G (2006) EGFR in colorectal cancer: more than a simple receptor. Ann Oncol 17:962-967

36. Cappuzzo F, Hirsch FR, Rossi E, Bartolini S, Ceresoli GL, Bemis L, Haney J, Witta S, Danenberg K, Domenichini I, Ludovini V, Magrini E, Gregorc V, Doglioni C, Sidoni A, Tonato M, Franklin WA, Crino L, Bunn PA Jr, Varella-Garcia M (2005) Epidermal growth factor receptor gene and protein and gefitinib sensitivity in non-small-cell lung cancer. $\mathrm{J}$ Natl Cancer Inst 97:643-655

37. Hijiya N, Miyawaki M, Kawahara K, Akamine S, Tsuji K, Kadota J, Akizuki S, Uchida T, Matsuura K, Tsukamoto Y, Moriyama M (2008) Phosphorylation status of epidermal growth factor receptor is closely associated with responsiveness to gefitinib in pulmonary adenocarcinoma. Hum Pathol 39:316-323

38. Barault L, Veyrie N, Jooste V, Lecorre D, Chapusot C, Ferraz JM, Lievre A, Cortet M, Bouvier AM, Rat P, Roignot P, Faivre J, Laurent-Puig P, Piard F (2008) Mutations in the RAS-MAPK, PI (3)K (phosphatidylinositol-3-OH kinase) signaling network correlate with poor survival in a population-based series of colon cancers. Int J Cancer 122:2255-2259

39. Tan YH, Liu Y, Eu KW, Ang PW, Li WQ, Salto-Tellez M, Iacopetta B, Soong R (2008) Detection of BRAF V600E mutation by pyrosequencing. Pathology 40:295-298

40. Calistri D, Rengucci C, Seymour I, Lattuneddu A, Polifemo AM, Monti F, Saragoni L, Amadori D (2005) Mutation analysis of p53, $\mathrm{K}$-ras, and BRAF genes in colorectal cancer progression. J Cell Physiol 204:484-488

41. Oliveira C, Pinto M, Duval A, Brennetot C, Domingo E, Espin E, Armengol M, Yamamoto H, Hamelin R, Seruca R, Schwartz S Jr (2003) BRAF mutations characterize colon but not gastric cancer with mismatch repair deficiency. Oncogene 22:9192-9196

42. Domingo E, Espin E, Armengol M, Oliveira C, Pinto M, Duval A, Brennetot C, Seruca R, Hamelin R, Yamamoto H, Schwartz S Jr (2004) Activated BRAF targets proximal colon tumors with mismatch repair deficiency and MLH1 inactivation. Genes Chromosomes Cancer 39:138-142

43. Ogino S, Cantor M, Kawasaki T, Brahmandam M, Kirkner GJ, Weisenberger DJ, Campan M, Laird PW, Loda M, Fuchs CS (2006) $\mathrm{CpG}$ island methylator phenotype (CIMP) of colorectal cancer is best characterised by quantitative DNA methylation analysis and prospective cohort studies. Gut 55:1000-1006

44. Rajagopalan H, Bardelli A, Lengauer C, Kinzler KW, Vogelstein B, Velculescu VE (2002) Tumorigenesis: RAF/RAS oncogenes and mismatch-repair status. Nature 418:934

45. Preto A, Figueiredo J, Velho S, Ribeiro AS, Soares P, Oliveira C, Seruca R (2008) BRAF provides proliferation and survival signals in MSI colorectal carcinoma cells displaying BRAF(V600E) but not KRAS mutations. J Pathol 214:320-327

46. Jhawer M, Goel S, Wilson AJ, Montagna C, Ling YH, Byun DS, Nasser S, Arango D, Shin J, Klampfer L, Augenlicht LH, Soler RP, Mariadason JM (2008) PIK3CA mutation/PTEN expression status predicts response of colon cancer cells to the epidermal growth factor receptor inhibitor cetuximab. Cancer Res 68:1953-1961

47. Ince WL, Jubb AM, Holden SN, Holmgren EB, Tobin P, Sridhar M, Hurwitz HI, Kabbinavar F, Novotny WF, Hillan KJ, Koeppen 
$\mathrm{H}$ (2005) Association of k-ras, b-raf, and p53 status with the treatment effect of bevacizumab. J Natl Cancer Inst 97:981-989

48. Lievre A, Bachet JB, Le CD, Boige V, Landi B, Emile JF, Cote JF, Tomasic G, Penna C, Ducreux M, Rougier P, Penault-Llorca F, Laurent-Puig P (2006) KRAS mutation status is predictive of response to cetuximab therapy in colorectal cancer. Cancer Res 66:3992-3995

49. Velho S, Oliveira C, Ferreira A, Ferreira AC, Suriano G, Schwartz S Jr, Duval A, Carneiro F, Machado JC, Hamelin R, Seruca R (2005) The prevalence of PIK3CA mutations in gastric and colon cancer. Eur J Cancer 41:1649-1654

50. Frattini M, Saletti P, Romagnani E, Martin V, Molinari F, Ghisletta M, Camponovo A, Etienne LL, Cavalli F, Mazzucchelli L (2007) PTEN loss of expression predicts cetuximab efficacy in metastatic colorectal cancer patients. Br J Cancer 97:1139-1145

51. Edkins S, O'Meara S, Parker A, Stevens C, Reis M, Jones S, Greenman C, Davies H, Dalgliesh G, Forbes S, Hunter C, Smith R, Stephens P, Goldstraw P, Nicholson A, Chan TL, Velculescu VE, Yuen ST, Leung SY, Stratton MR, Futreal PA (2006) Recurrent KRAS codon 146 mutations in human colorectal cancer. Cancer Biol Ther 5:928-932

52. Kosaka T, Yatabe Y, Endoh H, Kuwano H, Takahashi T, Mitsudomi T (2004) Mutations of the epidermal growth factor receptor gene in lung cancer: biological and clinical implications. Cancer Res 64:8919-8923

53. Oliveira C, Westra JL, Arango D, Ollikainen M, Domingo E, Ferreira A, Velho S, Niessen R, Lagerstedt K, Alhopuro P, Laiho P, Veiga I, Teixeira MR, Ligtenberg M, Kleibeuker JH, Sijmons RH, Plukker JT, Imai K, Lage P, Hamelin R, Albuquerque C, Schwartz S Jr, Lindblom A, Peltomaki P, Yamamoto H, Aaltonen LA, Seruca R, Hofstra RM (2004) Distinct patterns of KRAS mutations in colorectal carcinomas according to germline mismatch repair defects and hMLH1 methylation status. Hum Mol Genet 13:2303-2311

54. Russo A, Bazan V, Agnese V, Rodolico V, Gebbia N (2005) Prognostic and predictive factors in colorectal cancer: Kirsten Ras in CRC (RASCAL) and TP53CRC collaborative studies. Ann Oncol 16 Suppl 4:iv44-iv49

55. Samowitz WS, Curtin K, Schaffer D, Robertson M, Leppert M, Slattery ML (2000) Relationship of Ki-ras mutations in colon cancers to tumor location, stage, and survival: a population-based study. Cancer Epidemiol Biomarkers Prev 9:1193-1197

56. Andreyev HJ, Norman AR, Cunningham D, Oates J, Dix BR, Iacopetta BJ, Young J, Walsh T, Ward R, Hawkins N, Beranek M, Jandik P, Benamouzig R, Jullian E, Laurent-Puig P, Olschwang S, Muller O, Hoffmann I, Rabes HM, Zietz C, Troungos C, Valavanis C, Yuen ST, Ho JW, Croke CT, O'Donoghue DP, Giaretti W, Rapallo A, Russo A, Bazan V, Tanaka M, Omura K, Azuma T, Ohkusa T, Fujimori T, Ono Y, Pauly M, Faber C, Glaesener R, de Goeij AF, Arends JW, Andersen SN, Lovig T, Breivik J, Gaudernack G, Clausen OP, De Angelis PD, Meling GI, Rognum TO, Smith R, Goh HS, Font A, Rosell R, Sun XF, Zhang H, Benhattar J, Losi L, Lee JQ, Wang ST, Clarke PA, Bell S, Quirke P, Bubb VJ, Piris J, Cruickshank NR, Morton D, Fox JC, Al-Mulla F, Lees N, Hall CN, Snary D, Wilkinson K, Dillon D, Costa J, Pricolo VE, Finkelstein SD, Thebo JS, Senagore AJ, Halter SA, Wadler S, Malik S, Krtolica K, Urosevic N (2001) Kirsten ras mutations in patients with colorectal cancer: the 'RASCAL II' study. Br J Cancer 85:692-696

57. Zerbe LK, Dwyer-Nield LD, Fritz JM, Redente EF, Shroyer RJ, Conklin E, Kane S, Tucker C, Eckhardt SG, Gustafson DL, Iwata KK, Malkinson AM (2008) Inhibition by erlotinib of primary lung adenocarcinoma at an early stage in male mice. Cancer Chemother Pharmacol 62:605-620

58. Keller JW, Franklin JL, Graves-Deal R, Friedman DB, Whitwell CW, Coffey RJ (2007) Oncogenic KRAS provides a uniquely powerful and variable oncogenic contribution among RAS family members in the colonic epithelium. J Cell Physiol 210:740-749

59. Wang JY, Wang YH, Jao SW, Lu CY, Kuo CH, Hu HM, Hsieh JS, Chong IW, Cheng TL, Lin SR (2006) Molecular mechanisms underlying the tumorigenesis of colorectal adenomas: correlation to activated K-ras oncogene. Oncol Rep 16:1245-1252

60. Castagnola P, Giaretti W (2005) Mutant KRAS, chromosomal instability and prognosis in colorectal cancer. Biochim Biophys Acta 1756:115-125

61. Benvenuti S, Sartore-Bianchi A, Di NF, Zanon C, Moroni M, Veronese S, Siena S, Bardelli A (2007) Oncogenic activation of the RAS/RAF signaling pathway impairs the response of metastatic colorectal cancers to anti-epidermal growth factor receptor antibody therapies. Cancer Res 67:2643-2648

62. De RW, Piessevaux H, De SJ, Janssens M, De HG, Personeni N, Biesmans B, Van Laethem JL, Peeters M, Humblet Y, Van CE, Tejpar S (2008) KRAS wild-type state predicts survival and is associated to early radiological response in metastatic colorectal cancer treated with cetuximab. Ann Oncol 19:508-515

63. Di FF, Blanchard F, Charbonnier F, Le PF, Lamy A, Galais MP, Bastit L, Killian A, Sesboue R, Tuech JJ, Queuniet AM, Paillot B, Sabourin JC, Michot F, Michel P, Frebourg T (2007) Clinical relevance of KRAS mutation detection in metastatic colorectal cancer treated by Cetuximab plus chemotherapy. Br J Cancer 96:1166-1169

64. Khambata-Ford S, Garrett CR, Meropol NJ, Basik M, Harbison CT, Wu S, Wong TW, Huang X, Takimoto CH, Godwin AK, Tan BR, Krishnamurthi SS, Burris HA III, Poplin EA, Hidalgo M, Baselga J, Clark EA, Mauro DJ (2007) Expression of epiregulin and amphiregulin and K-ras mutation status predict disease control in metastatic colorectal cancer patients treated with cetuximab. J Clin Oncol 25:3230-3237

65. Lievre A, Bachet JB, Boige V, Cayre A, Le CD, Buc E, Ychou M, Bouche O, Landi B, Louvet C, Andre T, Bibeau F, Diebold MD, Rougier P, Ducreux M, Tomasic G, Emile JF, Penault-Llorca F, Laurent-Puig P (2008) KRAS mutations as an independent prognostic factor in patients with advanced colorectal cancer treated with cetuximab. J Clin Oncol 26:374-379

66. Juan T, Suggs S, Wolf M, Sarosi I, Freeman D, Oliner K, Bakkar A, Patterson SD (2008) A comparability study of 4 commercial KRAS tests. American Association for Cancer Research (AACR) Annual Meeting, April 12-16, 2008, Abstract \#1811

67. Kressner U, Bjorheim J, Westring S, Wahlberg SS, Pahlman L, Glimelius B, Lindmark G, Lindblom A, Borresen-Dale AL (1998) $\mathrm{Ki}$-ras mutations and prognosis in colorectal cancer. Eur J Cancer 34:518-521

68. Hayes VM, Westra JL, Verlind E, Bleeker W, Plukker JT, Hofstra RM, Buys CH (2000) New comprehensive denaturing-gradient-gel-electrophoresis assay for KRAS mutation detection applied to paraffinembedded tumours. Genes Chromosomes Cancer 29:309-314

69. Zhao C, Xu G, Shi X, Ma J, Lu S, Yang Q (2004) Detection of Kras exon 1 mutations by constant denaturant capillary electrophoresis. Biomed Chromatogr 18:538-541

70. Chaubert P, Bautista D, Benhattar J (1993) An improved method for rapid screening of DNA mutations by nonradioactive single-strand conformation polymorphism procedure. Biotechniques 15:586

71. Khanna M, Park P, Zirvi M, Cao W, Picon A, Day J, Paty P, Barany F (1999) Multiplex PCR/LDR for detection of K-ras mutations in primary colon tumors. Oncogene 18:27-38

72. Ogino S, Kawasaki T, Brahmandam M, Yan L, Cantor M, Namgyal C, Mino-Kenudson M, Lauwers GY, Loda M, Fuchs CS (2005) Sensitive sequencing method for KRAS mutation detection by pyrosequencing. J Mol Diagn 7:413-421

73. Poehlmann A, Kuester D, Meyer F, Lippert H, Roessner A, Schneider-Stock R (2007) K-ras mutation detection in colorectal cancer using the pyrosequencing technique. Pathol Res Pract 203:489-497 
74. Fox JC, England J, White P, Ellison G, Callaghan K, Charlesworth NR, Hehir J, McCarthy TL, Smith-Ravin J, Talbot IC, Snary D, Northover JM, Newton CR, Little S (1998) The detection of K-ras mutations in colorectal cancer using the amplification-refractory mutation system. Br J Cancer 77:1267-1274

75. van Heek NT, Clayton SJ, Sturm PD, Walker J, Gouma DJ, Noorduyn LA, Offerhaus GJ, Fox JC (2005) Comparison of the novel quantitative ARMS assay and an enriched PCR-ASO assay for K-ras mutations with conventional cytology on endobiliary brush cytology from 312 consecutive extrahepatic biliary stenoses. J Clin Pathol 58:1315-1320

76. Cross J (2008) DxS Ltd. Pharmacogenomics 9:463-467

77. Mixich F, Ioana M, Voinea F, Saftoiu A, Ciurea T (2007) Noninvasive detection through REMS-PCR technique of K-ras mutations in stool DNA of patients with colorectal cancer. J Gastrointestin Liver Dis 16:5-10

78. Amicarelli G, Shehi E, Makrigiorgos GM, Adlerstein D (2007) FLAG assay as a novel method for real-time signal generation during PCR: application to detection and genotyping of KRAS codon 12 mutations. Nucleic Acids Res 35:e131

79. Kimura K, Nagasaka T, Hoshizima N, Sasamoto H, Notohara K, Takeda M, Kominami K, Iishii T, Tanaka N, Matsubara N (2007)
No duplicate KRAS mutation is identified on the same allele in gastric or colorectal cancer cells with multiple KRAS mutations. J Int Med Res 35:450-457

80. Hashimoto M, Barany F, Xu F, Soper SA (2007) Serial processing of biological reactions using flow-through microfluidic devices: coupled PCR/LDR for the detection of low-abundant DNA point mutations. Analyst 132:913-921

81. Wabuyele MB, Farquar H, Stryjewski W, Hammer RP, Soper SA, Cheng YW, Barany F (2003) Approaching real-time molecular diagnostics: single-pair fluorescence resonance energy transfer (spFRET) detection for the analysis of low abundant point mutations in K-ras oncogenes. J Am Chem Soc 125:6937-6945

82. Li J, Zhong W (2007) Typing of multiple single-nucleotide polymorphisms by a microsphere-based rolling circle amplification assay. Anal Chem 79:9030-9038

83. Zhang P, Chu X, Xu X, Shen G, Yu R (2008) Electrochemical detection of point mutation based on surface ligation reaction and biometallization. Biosens Bioelectron 23:1435-1441

84. Syngal S, Stoffel E, Chung D, Willett C, Schoetz D, Schroy P, Jagadeesh D, Morel K, Ross M (2006) Detection of stool DNA mutations before and after treatment of colorectal neoplasia. Cancer 106:277-283 